\title{
Delivering Bad News: Crisis Communication Methods in Academic Libraries
}

\section{Brittany O’Neill and Rebecca Kelley}

\begin{abstract}
This exploratory study analyzed the specific crisis communication methods of academic libraries. A survey was sent to library staff at Association of Research Libraries member colleges and universities to describe if, who, when, and how they communicated bad news to their stakeholders for major, minor, and emerging crises. The findings show that respondents used multiple communication strategies, which varied based on the crisis. The data show that libraries communicated journal and database cancellations and health and safety emergencies more slowly than access issues and were more likely not to communicate those crises at all. Respondents also more frequently chose to communicate journal and database cancellations only when asked as compared to other crises. While access issues and health and safety emergencies were primarily communicated through social media and the library's website, stakeholders received communication about journal and database cancellations primarily through targeted emails from library liaisons, face-to-face meetings with faculty, and the library's website. These findings suggest that respondents communicated more quickly for minor crises but were more hesitant for crises that may have presented the potential for reputational harm. The varied responses between crisis types often conflicted with best practices for whether to deliver bad news and, if so, when and by whom. These findings indicate a need for academic libraries to develop comprehensive crisis communication plans that emphasize timeliness and transparency.
\end{abstract}

\section{Introduction}

Academic libraries encounter unique crises that arise from existing within a university. In recent years, the ongoing serials crisis has caused financial constraints that have led to difficult budget decisions, and the COVID-19 pandemic caused libraries to shutter or limit access to services, collections, and spaces. Though libraries are not to blame for these crises, these situations have forced libraries to communicate the bad news these crises create to their stakeholders. Though perhaps unanticipated, academic libraries need to have communication plans for these sorts of crises to disseminate information more quickly and effectively. The mishandling or lack of communication during a crisis, however minor, has the potential to create reputational harm and distrust. This study explores the external communication strategies of Association of Research Libraries (ARL) member colleges and universities for the many types of crises they

\footnotetext{
${ }^{*}$ Brittany O'Neill is Humanities E Social Sciences Librarian and Rebecca Kelley is Mass Communication Librarian at Louisiana State University; email: boneill@lsu.edu, rkell25@lsu.edu. @2021 Brittany O'Neill and Rebecca Kelley, Attribution-NonCommercial (https://creativecommons.org/licenses/by-nc/4.0/) CC BY-NC.
} 
may face. This study appears to be the first to address the specifics of how academic libraries communicate bad news for different types of crises: health and safety emergencies, access issues, and journal and database cancellations. Are libraries communicating about these crises with their stakeholders? Who is responsible for communicating about these crises? When are libraries informing their stakeholders about these crises? Through which channels are libraries communicating to their stakeholders? Do these strategies vary among different types of crises? The results of this study illuminate the need for detailed crisis communication plans that go beyond emergency preparedness. The authors draw on these findings and best practices from crisis communication literature to begin developing best practices for academic libraries.

\section{Literature Review}

Public relations and communication researchers have long established the necessity of organizations communicating to stakeholders during crises. ${ }^{1} \mathrm{~W}$. Timothy Coombs defines a crisis as "the perceived violation of ...stakeholder expectations that can create negative outcomes for stakeholders and/or the organization." A crisis is unpredictable but not necessarily unexpected; has potential to disrupt the organization in some way; and can threaten the organization, its industry, or the stakeholders. ${ }^{2}$ Above all, a crisis is perceptual, as the stakeholders' perception of an issue can influence whether an event develops into a crisis. ${ }^{3}$ Michael Kent argues that a crisis can also help determine the organization's future actions and how it relates with stakeholders moving forward. ${ }^{4}$

The communication and public relations literature address other terms that might seem analogous to crises: problems, issues, disasters, and emergencies. However, there are differences among these terms. Problems are recurring situations that reveal where the organization is vulnerable, ${ }^{5}$ while issues begin as problems but can escalate into full-blown crises if ignored or mishandled. ${ }^{6}$ Disasters and emergencies are similar in that they are both sudden and unexpected events; disasters usually occur through negligence or are produced by natural forces, while emergencies are usually unforeseen but require sudden and urgent action. ${ }^{7}$

However, these related terms share a common theme: each could potentially cause harm to the organization or its stakeholders. "Crisis" serves as the umbrella term under which problems, issues, disasters, and emergencies fall.

When a crisis occurs, organizations must deliver difficult information to stakeholders about the crisis. As Robert Bies notes, "bad news" is terminology common in social sciences and medicine to describe this type of information. Bies defines bad news as "information that results in a perceived loss by the receiver, and it creates cognitive, emotional, or behavioral deficits in the receiver after receiving the news." 8

As this study highlights communication strategies for multiple events, the authors use "crisis" in reference to any negative event that can disrupt the organization and "bad news" as the information about that crisis that could negatively impact their stakeholders.

\section{Crisis Communication in the Library Literature}

Much of the library literature on the topic of communication and public relations exists in the sphere of public libraries and does not focus specifically on crisis communication. ${ }^{9}$ An exception is The Library's Crisis Communication Planner. Though written with public libraries in mind, Jan Thenell provides a framework for planning ahead of crises, including gathering information, conducting a vulnerability audit, developing a communication team, and carrying out the plan. ${ }^{10}$ 
Another exception in the literature is Jodie Borgerding's study on the status of crisis communication planning in academic libraries. Borgerding divides crises into the categories of intentional versus unintentional; essentially, whether an individual or organization is at fault for the crisis or the crisis is the cause of circumstances out of individual control. Borgerding further categorizes these crises into impact levels: major, minor, and emerging, with these categories primarily concerning the degree to which the crisis is pressing. ${ }^{11}$ Borgerding illuminated which elements were present in libraries' crisis communication plans, such as identifying a spokesperson and channels for communication, but did not address what those specific methods were.

Crises-major, minor, or emerging - can present make-or-break moments for academic library leaders. ${ }^{12}$ Despite this risk, many academic library leaders may not be prepared or competent as crisis leaders or communicators due to insufficient experience and skills. ${ }^{13}$ This is unsurprising given that crisis management is only moderately and indirectly represented in library and information science curricula, and only around 35 percent of the curricula includes education on communication. ${ }^{14}$

Crises academic libraries may face are not necessarily unique to those institutions. These may include budget cuts, ${ }^{15}$ trimmed hours, closures, ${ }^{16}$ infestations of pests ${ }^{17}$ and mold ${ }^{18}$ serials cancellations ${ }_{1}^{19}$ power outages ${ }^{20}$ shootings, ${ }^{21}$ and floods. ${ }^{22}$ However, the multilayered environment in which academic libraries exist as part of a larger institution complicate those crises. ${ }^{23}$ For this reason, the authors chose to include crisis communication literature from the field of higher education as well. Although there are established best practices for crisis communication planning in the public relations literature, best practices that fit the unique situations of academic libraries have yet to be established. What follow are best practices for delivering bad news from the crisis communication, library, and higher education literature.

\section{Crisis Communication Planning}

When leaders lack the communication skills on which to fall back in times of crisis, proper planning is necessary to prevent or de-escalate a crisis. Planning mitigates and manages risks that result from these situations. ${ }^{24}$ Organizations should select a crisis management team that represents all major functional divisions of the organization; individuals from different departments can provide unique insights and help address operational, legal, communication, and administrative concerns before and during a crisis. ${ }^{25}$

The crisis communication team should thoroughly research the organization's vulnerabilities and forecast potential crises; the team uses this information to create a crisis communication plan, which can outline how to manage a crisis. ${ }^{26}$ Since there is no way to predict every crisis, the crisis communication team should be ready to deal with any unanticipated challenge. ${ }^{27}$ Ian Mitroff, Michael Diamond, and C. Murat Alpaslan suggest that, even if a crisis is not planned for, having a good crisis communication team can help an institution recover "faster and cheaper." 28

Many academic libraries and higher education institutions as a whole lack crisis communication plans; in particular, they are overprepared for disaster but less prepared for smaller crises..$^{29}$ More than half of academic libraries surveyed in Borgerding's study did not have a crisis communication plan, ${ }^{30}$ and many of those with plans were unsure about aspects of the protocol. ${ }^{31}$ This demonstrates the need for practical guides to help academic libraries create better plans. ${ }^{32}$ Borgerding suggests that plans should include who communicates bad news, who the stakeholders are, which types of crises the institution might encounter, and the strategy for how to communicate bad news. 


\section{Why Communicate Bad News?}

The literature is in agreement that organizations must communicate bad news to stakeholders, as the failure to communicate may have a more significant negative impact on reputation than the crisis itself. ${ }^{33}$ Just as a crisis is perceptual, an organization's reputation is based on how the stakeholders perceive the organization and how well this meets the stakeholders' expectations. ${ }^{34}$ "Direct and mediated contact" with stakeholders creates an organization's reputation; therefore, ineffective communication during a crisis can damage this. ${ }^{35}$ In addition to preserving reputation, libraries can use effective communication to promote services, build support, and develop new partnerships. ${ }^{36}$

\section{Who Should Communicate Bad News?}

Who should be responsible for communication varies in the literature. Thenell suggests having one designated spokesperson for a crisis, ${ }^{37}$ while Coombs suggests selecting and training multiple spokespersons in advance of a crisis to speak as one voice for the organization. ${ }^{38}$ If multiple spokespersons share the responsibility for communication, the use of a single voice is imperative. ${ }^{39}$ While the spokesperson on the team may not necessarily be a dean or director, administration must set the direction for communication and properly disseminate the information to the team to ensure that a consistent message is delivered. ${ }^{40}$

In Borgerding's survey, most respondents had either a public relations or communications staff member or library director who was primarily responsible for communication, and many had spokespeople identified in their crisis communication plans. ${ }^{41}$ However, a significant number of respondents did not know who was responsible for communication, the responsibility belonged to no one in particular, or the person responsible depended on the situation. Borgerding's study identified who was responsible for library communication in general, but not if that spokesperson differed by crisis.

\section{When Should Bad News Be Communicated?}

In timing the delivery of bad news, the literature recommends responding as quickly as possible, but only after all the facts are known and a plan is in place. ${ }^{42}$ If the outcome of the bad news is certain, even if the cause is uncertain, a quick response and frequent updates can bolster trust. ${ }^{43}$ Timely notification demonstrates that the organization has active control of the situation..$^{44}$ Slow responses, whether because there is no plan yet in place or because news spreads before the institution can communicate it, can cause stakeholders to lose trust in the organization. ${ }^{45}$ However, if the outcome is uncertain, speed can be problematic, as information shared could be inaccurate. ${ }^{46}$ The need for a quick response must be balanced with the potential cost of sharing inaccurate information, and it may be best to wait to disclose bad news until more information can be gathered about the outcome ${ }^{47}$ Regardless of whether the bad news is publicized, the literature suggests that there is a strong need for transparency with stakeholders regarding the situations that may cause crises, such as budget constraints, to garner support early. ${ }^{48}$

\section{What Communication Methods Should Be Used?}

There is little practical literature regarding the best media for communicating bad news in higher education and academic libraries. The crisis communication literature does not agree on which communication method organizations should use during a crisis; instead, 
organizations should have a current crisis communication plan that will guide them on what method is appropriate for each specific crisis, as each may require a different approach. ${ }^{49}$

To communicate effectively during a crisis, an organization needs to identify its target audience and then use a variety of channels that will reach those stakeholders. ${ }^{50}$ Thenell argues that communication should always be two-way. ${ }^{51}$ Two-way communication can be particularly effective in not only sharing bad news, but also communicating value. ${ }^{52}$

In academic libraries, communication often goes through pre-existing lines of communication, such as newsletters, emails, faculty meetings, library websites, and social media. ${ }^{53}$ In most of these cases, more than one medium of communication-and both targeted and general strategies - were used.

The organization's website can also be useful as a communication channel during a crisis; this allows the organization to deliver the crisis response directly to the stakeholders and control the message.$^{54}$ Organizations should consider a social media response if the stakeholders need to be made aware of an immediate risk or if the crisis is taking place on social media. ${ }^{55}$ Otherwise, Coombs urges caution, as social media "can create an expectation for interaction," so the organization must have the resources to quickly and adequately address the additional information requests generated by social media. ${ }^{56}$

\section{Methods}

This study used a cross-sectional survey, including qualitative and quantitative methods, to seek details of crisis communication strategies in academic libraries. Respondents were asked questions about whether bad news was communicated, who delivered bad news, how it was communicated, and when communication occurred for several different categories of crises (see appendix). Participants were asked questions regarding six examples of crises. For the purposes of this study, the authors only analyzed data from three of those crises that best represent what Borgerding describes as major (health and safety emergencies), minor (access issues), and emerging (journal or database cancellations) impact levels. ${ }^{57}$ Additional questions asked for the respondent's job role, institution size, and degrees held, as well as qualitative prompts to suggest other examples of bad news missed in this survey and to describe their stakeholders' response to their communication. This data is not included in this study and will be explored in future research. Respondents were also asked to identify their institution to allow the investigators to differentiate among responses and prevent redundant responses. This identifying information has been kept anonymous and is excluded from this study.

Colleges and universities that were members of the Association of Research Libraries as of April 2019 were chosen $(n=116)$ to gather a sample of medium- to large-sized research institutions. The investigators compiled a list of qualifying institutions and used their online directories to seek out libraries' communication/public relations staff as first contacts. If the library appeared not to have this staff member, deans or heads of public services (or their equivalents) were chosen. The authors' institution was included in the sample.

An application was submitted to the Louisiana State University Institutional Review Board in March 2019 and was exempt from review. The survey was created using Qualtrics survey software and distributed via email using personal links in April 2019. The survey closed in May of 2019. 


\section{Results}

The total number of responses to the survey was 42 . Thirty-six responses were complete enough to analyze, resulting in a response rate of 31 percent.

This section presents data related to whether bad news was delivered for a given crisis type, and if so, by whom, when, and through which channels. The results are organized by crisis type (emerging, minor, and major). Tables are presented under the emerging crisis subheading but are referred to throughout this section.

\section{Emerging Crisis: Journal or Database Cancellations}

The survey respondents were asked whether their library communicated journal or database cancellations to their campus stakeholders. The majority $(n=27,79 \%)$ of respondents reported their libraries did communicate journal or database cancellations to their campus stakeholders (see table 1). Twelve percent $(n=4 ; 12 \%)$ of respondents reported their libraries had not experienced journal or database cancellations, while nine percent $(n=3,9 \%)$ reported they did not inform their stakeholders of these cancellations.

\begin{tabular}{|c|c|c|c|c|c|c|}
\hline \multicolumn{7}{|c|}{$\begin{array}{c}\text { TABLE } 1 \\
\text { Communication of Bad News, by Crisis }\end{array}$} \\
\hline \multirow[b]{2}{*}{ Yes } & \multicolumn{2}{|c|}{$\begin{array}{l}\text { Journal or Database } \\
\text { Cancellations }(n=34)\end{array}$} & \multicolumn{2}{|c|}{$\begin{array}{l}\text { Access Issues } \\
(n=30)\end{array}$} & \multicolumn{2}{|c|}{$\begin{array}{c}\text { Health \& Safety } \\
\text { Emergencies }(n=28)\end{array}$} \\
\hline & 27 & $79 \%$ & 28 & $93 \%$ & 15 & $54 \%$ \\
\hline No & 3 & $9 \%$ & 2 & $7 \%$ & 7 & $25 \%$ \\
\hline $\mathrm{n} / \mathrm{a}$ & 4 & $12 \%$ & 0 & $0 \%$ & 6 & $21 \%$ \\
\hline
\end{tabular}

When asked who communicated cancellations to campus stakeholders, respondents indicated that this responsibility was spread across library departments (see table 2). Participants could select more than one answer. Liaison librarians $(n=21,30 \%)$ were most likely to publicize this type of bad news to stakeholders, followed by library administrators $(n=16$, $23 \%)$ and the library communication $(n=12,17 \%)$ and collection development $(n=11,15 \%)$ departments.

\begin{tabular}{|c|c|c|c|c|c|c|}
\hline \multicolumn{7}{|c|}{$\begin{array}{c}\text { TABLE } 2 \\
\text { Who Communicated Bad News, by Crisis* }\end{array}$} \\
\hline \multirow[b]{2}{*}{ Liaison Librarians } & \multicolumn{2}{|c|}{$\begin{array}{c}\text { Journal or Database } \\
\text { Cancellations } \\
(\mathbf{n}=\mathbf{3 4})\end{array}$} & \multicolumn{2}{|c|}{$\begin{array}{l}\text { Access Issues } \\
\quad(n=30)\end{array}$} & \multicolumn{2}{|c|}{$\begin{array}{c}\text { Health \& Safety } \\
\text { Emergencies } \\
(\mathbf{n}=\mathbf{2 8})\end{array}$} \\
\hline & 21 & $30 \%$ & 9 & $18 \%$ & 2 & $6 \%$ \\
\hline Collection Development Department & 11 & $15 \%$ & 1 & $2 \%$ & 0 & $0 \%$ \\
\hline Public Services Department & 5 & $7 \%$ & 12 & $24 \%$ & 6 & $17 \%$ \\
\hline Library Communication Department & 12 & $17 \%$ & 16 & $32 \%$ & 11 & $31 \%$ \\
\hline Library Administration & 16 & $23 \%$ & 3 & $6 \%$ & 6 & $17 \%$ \\
\hline University & 4 & $6 \%$ & 3 & $6 \%$ & 7 & $20 \%$ \\
\hline Other & 2 & $3 \%$ & 6 & $12 \%$ & 3 & $9 \%$ \\
\hline
\end{tabular}


Respondents were asked when their library communicated journal or database cancellations to campus stakeholders (see table 3). Most respondents said their libraries waited before communicating: either until more information was gathered and a plan was in place $(\mathrm{n}=15$, $31 \%)$ or until after library staff were notified $(n=13,27 \%)$.

\begin{tabular}{|l|c|c|c|c|c|c|}
\hline \multicolumn{7}{|c|}{ WABLE 3 } \\
\hline & $\begin{array}{c}\text { Journal or Database } \\
\text { Cancellations } \\
\text { (n=34) }\end{array}$ & $\begin{array}{c}\text { Access Issues } \\
\text { (n=30) }\end{array}$ & $\begin{array}{c}\text { Health \& Safety } \\
\text { Emergencies } \\
\text { (n=28) }\end{array}$ \\
\hline Immediately & 7 & $14 \%$ & 20 & $53 \%$ & 6 & $22 \%$ \\
\hline After internal communication w/library staff & 13 & $27 \%$ & 8 & $21 \%$ & 4 & $15 \%$ \\
\hline $\begin{array}{l}\text { Once more information is gathered and plan } \\
\text { is in place }\end{array}$ & 15 & $31 \%$ & 7 & $18 \%$ & 7 & $26 \%$ \\
\hline Once stakeholders ask questions & 4 & $8 \%$ & 1 & $3 \%$ & 0 & $0 \%$ \\
\hline After message is approved by university & 5 & $10 \%$ & 0 & $0 \%$ & 6 & $22 \%$ \\
\hline Other & 5 & $10 \%$ & 2 & $5 \%$ & 4 & $15 \%$ \\
\hline *respondents could select multiple answers & & & & & & \\
\hline
\end{tabular}

Respondents were asked which communication channels their library used to inform faculty and students about these cancellations and could select multiple answers. A variety of methods were used in communicating this type of bad news to library stakeholders (see table 4); the most frequently cited were emails from liaisons ( $\mathrm{n}=24,24 \%)$, presentations at faculty meetings $(n=16,16 \%)$, and a message posted on the library website $(n=16,16 \%)$. Other commonly used communication channels were campuswide emails from the library $(\mathrm{n}=11,11 \%)$ and emails from library administration to academic departments $(\mathrm{n}=10,10 \%)$.

\begin{tabular}{|l|c|c|c|c|c|c|}
\hline \multicolumn{7}{|c|}{ WABLE 4 } \\
& $\begin{array}{c}\text { Wournal or Database } \\
\text { Cancellations } \\
\text { (n= 34) }\end{array}$ & $\begin{array}{c}\text { Access Issues } \\
\text { (n= 30) }\end{array}$ & $\begin{array}{c}\text { Health \& Safety } \\
\text { Emergencies } \\
\text { (n = 28) }\end{array}$ \\
\hline Presentation at faculty meeting & 16 & $16 \%$ & 5 & $7 \%$ & 1 & $2 \%$ \\
\hline Email from liaison & 24 & $24 \%$ & 10 & $14 \%$ & 3 & $7 \%$ \\
\hline Email from collection development & 9 & $9 \%$ & 1 & $1 \%$ & 0 & 0 \\
\hline Email from library administration & 10 & $10 \%$ & 2 & $3 \%$ & 2 & $5 \%$ \\
\hline Library social media & 8 & $8 \%$ & 20 & $27 \%$ & 10 & $23 \%$ \\
\hline Email from library (campuswide) & 11 & $11 \%$ & 3 & $4 \%$ & 6 & $14 \%$ \\
\hline Library website & 16 & $16 \%$ & 26 & $36 \%$ & 10 & $23 \%$ \\
\hline University website/email/social media & 4 & $4 \%$ & 3 & $4 \%$ & 7 & $16 \%$ \\
\hline Other & 1 & $1 \%$ & 3 & $4 \%$ & 5 & $11 \%$ \\
\hline *respondents could select multiple answers & & & & & \\
\hline
\end{tabular}




\section{Minor Crisis: Access Issues}

Survey respondents were asked whether their library communicated access issues to their campus stakeholders. The authors provided examples of potential access issues, which included database outages and library department closures. Ninety-three percent $(n=28)$ of respondents reported that their libraries communicated access issues to campus stakeholders, while only 7 percent $(n=2)$ acknowledged that this crisis was not communicated (see table 1 ).

When asked who communicated bad news about library access issues, respondents noted that the library's communication department $(n=16,32 \%)$, public services department $(n=$ $12,24 \%$ ), and library liaisons ( $n=9,18 \%$ ) were most often tasked with this responsibility (see table 2). Respondents were able to select multiple answers.

When asked about the timing of the communication related to access issues, 53 percent of respondents $(n=20)$ said their library responded immediately (see table 3$)$. Other libraries either waited until after library staff were notified $(n=8,21 \%)$ or until more information was gathered to put a plan in place $(n=7,18 \%)$.

Study participants were asked how their library communicated access issues to campus stakeholders and were encouraged to select all communication methods that applied to their library. Most respondents reported the use of the library's website $(n=26,36 \%)$ and social media channels $(n=20,27 \%)$ to alert stakeholders to this type of bad news (see table 4). Another common communication method used by libraries was to task liaison librarians with emailing their respective academic colleges or departments with this information $(n=10,14 \%)$.

\section{Major Crisis: Health and Safety Emergencies}

Respondents were asked whether their libraries communicated health and safety emergencies to stakeholders on their campus. The authors included examples of the types of crises that could be viewed as health or safety emergencies: flooding, infestations, and criminal activity. Fifty-four percent $(n=15)$ of respondents indicated their library communicated health and safety emergencies to campus stakeholders (see table 1 ). The remaining respondents either said they did not communicate this type of crisis $(n=7,25 \%)$ or had not experienced any health and safety crises in their library $(n=6,21 \%)$.

Respondents were asked who communicated library-related health and safety crises to campus stakeholders. A mix of library and university departments were used to disseminate this bad news to campus stakeholders (see table 2). The crisis was most likely to be reported by the library's communication department $(n=11,31 \%)$. Respondents also indicated that library administrators $(n=6,17 \%)$ and public service departments $(n=6,17 \%)$ communicate this type of emergency to campus. However, 20 percent of respondents $(n=7)$ indicated that their university's communication department handled communication about health and safety crises. Participants could select more than one answer.

Study participants were asked when their library communicated health and safety emergencies to their campus (see table 3). Twenty-two percent of respondents $(n=6)$ indicated that their libraries immediately communicated health and safety emergencies to stakeholders. However, the data shows that most respondents waited to communicate this type of crisis: either to gather more information and form a plan $(n=7,26 \%)$, to wait for university approval of the response $(n=6,22 \%)$, or to notify library staff first $(n=4,15 \%)$. Four respondents $(15 \%)$ selected "other" and noted that the timing of communication depended on the nature and specifics of the crisis. 
When asked what communication channels were used to inform stakeholders of health and safety emergencies at their library, respondents noted a variety of methods (see table 4). Most participants reported the use of their library's website $(n=10,23 \%)$ and social media ( $n$ $=10,23 \%$ ) to communicate this type of crisis. Other popular methods to communicate libraryrelated health and safety emergencies included university-led communication channels $(n=7$, $16 \%)$ and campuswide emails from the library $(n=6,14 \%)$. Respondents could select multiple answers to this question.

\section{Discussion}

\section{Was Bad News Communicated?}

The results indicated that more libraries notified stakeholders about access issues than other crises, such as cancellations or health and safety emergencies. This can be partly explained by a portion of respondents noting that they had not experienced journal or database cancellations or health and safety emergencies. Nonetheless, when respondents experienced either journal or database cancellations or health and safety emergencies, more opted not to communicate in those cases than for access issues. Access issues, such as database outages, are usually temporary problems that can be quickly resolved and are unintentional on the part of the library; therefore, there may be less concern about potential reputational harm if libraries share the information.

While a majority of libraries alerted stakeholders to journal or database cancellations, 9 percent did not. Contrary to best practices in the literature, which recommend a timely response, ${ }^{58}$ these libraries withheld this type of bad news from their stakeholders.

A surprising finding was that 25 percent of libraries did not communicate health and safety emergencies to their stakeholders. This type of crisis has the potential to negatively impact the reputation and safety of the entire university. Best practices recommend that organizations should control the message by communicating with stakeholders, as this could lessen any potential damage to the institution's reputation. ${ }^{59}$

While academic libraries more often communicated minor crises (such as access issues), there is room for improvement when faced with emerging and major crises. The considerable number of respondents who did not communicate about certain crises goes against best practices, which indicate that the failure to communicate is a mistake that could worsen the situation. ${ }^{60}$ As Borgerding's research proposes, academic libraries should prepare crisis communication plans in advance to effectively communicate bad news for a variety of crises. ${ }^{61}$

\section{Who Communicated Bad News?}

The data demonstrated that the departments that communicated bad news to stakeholders varied by crisis. While respondents more frequently chose library communication departments to communicate, especially for access issues and health and safety emergencies, the majority of respondents still entrusted this communication to other library or university units. This indicates that these institutions either do not have a communication department, or, if they do, they have delegated this responsibility to other units. It is reasonable that 20 percent of respondents indicated that the university at large communicated health and safety emergencies, given the potential impact on the entire campus. The parties responsible varied among crises, and there are no best practices regarding which individuals should be responsible for communication. As such, Borgerding's suggestion to have a clear plan that specifies who is 
responsible for crisis communication is necessary until those best practices are established, especially given her finding that few libraries had such plans. ${ }^{62}$

Respondents more frequently chose library liaisons and administrators to communicate journal or database cancellations. Liaisons may use a more targeted and personalized approach that could prevent reputational harm, while the authority of administration can provide the sense that the situation is under control. However, given that respondents also frequently selected other departments to share this news, this reiterates the importance of using consistent messaging in one voice for dissemination to stakeholders. ${ }^{63}$

\section{When Was Bad News Communicated?}

The trends in the data regarding when bad news is communicated indicated that libraries communicated unintentional or minor crises more quickly. The majority of respondents indicated that they communicated access issues immediately. Crises such as journal or database cancellations are typically emerging and involve a slower decision process. This crisis was unsurprisingly communicated later; most respondents indicated that they communicated the bad news to their stakeholders once a plan was in place and/or staff had been alerted. The option of only communicating when asked by stakeholders was also more frequently selected for journal or database cancellations than for other crises. The results show a more hesitant approach to communication in these instances, likely because cancellations present risks for reputational harm. However, best practices indicate that transparency in these situations could foster trust and reduce the risk of reputational harm. ${ }^{64}$

The results for the timing of health and safety emergency communication were more varied. Despite potential safety concerns, many respondents indicated that they waited to communicate, either after communicating internally, once a plan was in place or after the university approved the message. However, this is likely due to the range of severity for emergencies a library may encounter; all of the respondents who chose "other" indicated that the timing would depend on the immediacy of the emergency. These results reflect Baker and Hernandez's assertion that, while quick response times are preferable, waiting to disclose bad news until more information can be gathered should be considered when negative outcomes for stakeholders are still uncertain. ${ }^{65}$

Some respondents waited for university approval before communicating both health and safety emergencies and journal or database cancellations, but no respondents chose this option for access issues. This may reflect Borgerding's impact levels, with health and safety emergencies (major) and journal or database cancellations (emerging) having a more significant impact and perceived severity than access issues (minor).$^{66}$

\section{What Communication Methods Were Used?}

Because respondents had the option to choose multiple modes of communication, responses varied widely, and respondents frequently employed more than one channel of communication. This finding was expected, as there are no best practices for channels of communication to use when delivering bad news. As academic libraries' collections are increasingly digital and individuals more frequently seek information online, it is logical that respondents most frequently communicated access issues through library websites and social media. Respondents used broad-reaching online communication methods such as their library's website and social media for health and safety emergencies, which present significant potential for reputational 
harm. This supports Coombs' argument that the use of social media and websites can allow organizations to control the message. ${ }^{67}$ The option of online communication through university channels was selected more frequently for health and safety emergencies than the other crises analyzed in this study, possibly because these emergencies can impact the entire university community. Most respondents who selected "other" for how they communicated a health and safety emergency stated that the method would depend on the particular emergency at hand.

Responses regarding journal or database cancellations indicated a much more targeted approach; respondents chose emails from liaisons and face-to-face conversations at faculty meetings more frequently for this crisis than for others. These findings reflect best practices from Thenell and Garczynski, who suggest that opportunities for two-way discussion and reassurance are effective in preserving reputation and communicating value. ${ }^{68}$

\section{Limitations}

This study has potential limitations. The authors chose ARL institutions to represent the communication practices of medium-to-large research libraries, so the findings do not represent all academic libraries, where staff size, institutional organization, and priorities may differ from the current sample. In addition, the usable response rate (31 percent of ARL libraries) should be noted as representative but not comprehensive of all ARL libraries. The authors determined the usable response rate as unique participants who completed more than 50 percent of the survey; this is reflected in the lower response rate to questions that appeared later in the survey. The authors selected participants based on their job titles, so the respondents' positions may also have influenced their responses. Furthermore, the methods used relied on the authors' inclusion of as many options as possible in the clearest language, so crisis types on which participants were surveyed were not comprehensive. To mitigate this, the authors included an "other" option for most questions. Some respondents contacted the authors to indicate that they would have appreciated a feature to provide explanations for their answers or an option to select that their answers might vary with specific situations. Future research may include a wider sample of academic libraries and consider these nuances in the development of their methods and instruments.

\section{Conclusion}

While previous studies have explored the existence of crisis communication plans in academic libraries and who is responsible for general communication, this study analyzed academic libraries' specific crisis communication methods and how they might vary depending on the crisis. The results indicate that the communication strategies used by academic libraries when faced with a crisis varied significantly based on the impact level of the crisis. In addition, there were a sizable number of write-in responses indicating that their methods would vary even within a crisis type, based on the individual crisis. These findings demonstrate that some libraries are disregarding best practices. Additionally, best practices have yet to be established for the specific communication channels to use when faced with varying crises, and there are few best practices for crisis communication specific to academic libraries. This further emphasizes the need for developing comprehensive crisis communication plans that include broad steps such as vulnerability audits and establishing a crisis communication team. Libraries should also develop targeted plans for individual crises that may require different spokespeople, communication channels, or timing considerations. 
Furthermore, the findings indicate some hesitancy or reluctance to communicate bad news, especially for those crises that may present a more significant negative impact on a library's reputation. Best practices indicate that a careful balance of timing and informationgathering in the communication of bad news is vital, but libraries should still communicate about these crises. As one respondent stated, "The faster an issue is communicated and the more transparent communication is, the more favorable our [stakeholders'] reactions tend to be." Library administration and crisis communication teams should consider the potential value added through transparency when making their crisis communication plan.

Future research should investigate the effectiveness of these communication methods to establish best practices for academic libraries. Since most academic libraries shifted into crisis mode as a result of the COVID-19 pandemic, future research should explore how academic libraries communicated closures to stakeholders and whether this crisis spurred the evaluation of communication methods or the creation of crisis communication plans. Future research should also evaluate the public relations skills and training of library staff and the importance of that background in developing effective crisis communication plans.

\section{Acknowledgments}

The authors would like to thank Kelly Blessinger, Andrea Hebert, Paul Hrycaj, and Allen LeBlanc for their insightful feedback during the development and editing of this manuscript. 


\section{APPENDIX. Survey Instrument}

Thank you for participating in this survey. Your participation is voluntary. The purpose of this survey is to gather information about how academic libraries communicate bad news to their stakeholders. If you agree to participate, you will be asked to identify communication strategies for different scenarios. This should take no more than 15 minutes.

Results of the study may be published, but identifying information will not be published. Names of participants will not be gathered. Subject identity will remain confidential unless disclosure is required by law.

If you have any questions about the survey, please contact the authors. This survey was submitted to the Louisiana State University Institutional Review Board and was determined not to require IRB approval or review.

1. What is your institution?

\{select university from a drop-down list of ARL institutions\}

2. How many employees work at your library?
$1-10$
$\square \quad 11-25$
$\square \quad 26-50$
$51-100$
101 or more

3. What is your role at your library?

I am an administrator (such as a dean/director/associate dean)

- I am a director/specialist/coordinator of communications/public relations

I am a liaison librarian/subject specialist

$\square \quad$ Other (please describe):

4. What degrees do you hold? Check all that apply.

$\square$ Master in Library and Information Science

- Communications/public relations or related field

$\square \quad$ Other (please describe):

\section{Budget Cuts}

5. Does your library communicate budget cuts to your campus stakeholders (faculty, students, and others)?
$\square$ Yes
$\square$ No
I don't know
- We have not had this event

\{If "I don't know" or "we have not had this event," skip to question 6.\} \{If "no," skip to question 5D.\}

5A. Who communicates budget cuts to your campus stakeholders? Check all that apply.

Library administration

$\square$ Library communication/PR department 
$\square$ University administration or communication department

$\square$ Collection development

$\square \quad$ Liaison librarians

$\square$ Access/public services

$\square$ Other (please describe):

5B. How are budget cuts communicated to your stakeholders? Check all that apply.

$\square \quad$ Libraries website

口 Campuswide email/newsletter from library

$\square \quad$ Library social media

$\square$ University website/email/social media

$\square \quad$ Email from liaison to academic units

$\square \quad$ Email from administration to academic units

$\square$ Email from collection development/management to academic units

$\square \quad$ Face-to-face at faculty meeting

$\square$ Other (please describe):

5C. When are budget cuts communicated to your stakeholders? Check all that apply.

$\square$ Immediately

$\square \quad$ After internal communication with library staff

$\square \quad$ After message is approved by university

$\square$ Once more information is gathered and a plan is in place

$\square$ When we start receiving questions from stakeholders/media

$\square$ Other (please describe):

5D. If your library does not communicate budget cuts, why not?

$\square \quad$ To minimize negative publicity

$\square \quad$ To minimize complaints

$\square \quad$ To buy time/hope to fix situation

$\square \quad$ Following orders from library administration

$\square$ Following orders from university administration

$\square \quad$ I don't know why

$\square$ We did not feel it should be communicated

$\square$ Communication is the responsibility of a different campus unit

$\square \quad$ Other (please describe):

\section{Journal or Database Cancellations}

6. Does your library communicate journal or database cancellations to your campus stakeholders (faculty, students, and other stakeholders)?

$\square$ Yes

$\square \quad$ No

I don't know

$\square \quad$ We have not had this event

\{If "I don't know" or "we have not had this event," skip to question 7.\}

\{If "no," skip to question 6D. $\}$

6A. Who communicates journal or database cancellations to your campus stakeholders? Check all that apply.

$\square$ Library administration 
口 Library communication/PR department

$\square$ University administration or communication department

$\square$ Collection development

$\square$ Liaison librarians

$\square \quad$ Access/public services

$\square \quad$ Other (please describe):

6B. How are journal or database cancellations communicated to your stakeholders? Check all that apply.

$\square \quad$ Libraries website

- Campuswide email/newsletter from library

$\square$ Library social media

$\square$ University website/email/social media

$\square \quad$ Email from liaison to academic units

$\square \quad$ Email from administration to academic units

$\square$ Email from collection development/management to academic units

$\square \quad$ Face-to-face at faculty meeting

$\square$ Other (please describe):

6C. When are journal or database cancellations communicated to your stakeholders? Check all that apply.

$\square$ Immediately

․ After internal communication with library staff

$\square$ After message is approved by university

$\square$ Once more information is gathered and a plan is in place

$\square$ When we start receiving questions from stakeholders/media

$\square$ Other (please describe):

6D. If your library does not communicate journal or database cancellations, why not? Check all that apply.

$\square \quad$ To minimize negative publicity

$\square$ To minimize complaints

ㅁ To buy time/hope to fix situation

$\square$ Following orders from library administration

$\square$ Following orders from university administration

$\square \quad$ I don't know why

$\square$ We did not feel it should be communicated

$\square$ Communication is the responsibility of a different campus unit

$\square \quad$ Other (please describe):

\section{Shortened Hours}

7. Does your library communicate shortened hours to your campus stakeholders (faculty, students, and others)?

$\square$ Yes

$\square$ No

I don't know

$\square$ We have not had this event

\{If "I don't know" or "we have not had this event," skip to question 8.\} 
\{If "no," skip to question 7D. $\}$

7A. Who communicates shortened hours to your campus stakeholders? Check all that apply.

$\square$ Library administration

$\square$ Library communication/PR department

$\square$ University administration or communication department

$\square$ Collection development

$\square \quad$ Liaison librarians

$\square$ Access/public services

$\square \quad$ Other (please describe):

7B. How are shortened hours communicated to your stakeholders? Check all that apply.

$\square$ Libraries website

$\square$ Campuswide email/newsletter from library

$\square \quad$ Library social media

$\square$ University website/email/social media

$\square \quad$ Email from liaison to academic units

$\square$ Email from administration to academic units

$\square$ Email from collection development/management to academic units

$\square \quad$ Face-to-face at faculty meeting

$\square$ Other (please describe):

7C. When are shortened hours communicated to your stakeholders? Check all that apply.

$\square$ Immediately

$\square \quad$ After internal communication with library staff

$\square \quad$ After message is approved by university

$\square$ Once more information is gathered and a plan is in place

$\square$ When we start receiving questions from stakeholders/media

$\square$ Other (please describe):

7D. If your library does not communicate shortened hours, why not? Check all that apply.

$\square \quad$ To minimize negative publicity

$\square \quad$ To minimize complaints

$\square \quad$ To buy time/hope to fix situation

$\square$ Following orders from library administration

$\square$ Following orders from university administration

$\square \quad$ I don't know why

$\square$ We did not feel it should be communicated

$\square$ Communication is the responsibility of a different campus unit

$\square \quad$ Other (please describe):

\section{Staff Reductions}

8. Does your library communicate staff reductions to your campus stakeholders (faculty, students, and others)?

$\square$ Yes

$\square \quad$ No

$\square$ I don't know

$\square$ We have not had this event

\{If "I don't know" or "we have not had this event," skip to question 9.\} 
\{If "no," skip to question 8D.\}

8A. Who communicates staff reductions to your campus stakeholders? Check all that apply.

$\square$ Library administration

$\square$ Library communication/PR department

$\square$ University administration or communication department

$\square$ Collection development

$\square$ Liaison librarians

$\square$ Access/public services

$\square$ Other (please describe):

8B. How are staff reductions communicated to your stakeholders? Check all that apply.

$\square$ Libraries website

- Campuswide email/newsletter from library

$\square$ Library social media

$\square$ University website/email/social media

$\square \quad$ Email from liaison to academic units

$\square$ Email from administration to academic units

$\square$ Email from collection development/management to academic units

$\square \quad$ Face-to-face at faculty meeting

$\square \quad$ Other (please describe):

8C. When are staff reductions communicated to your stakeholders? Check all that apply.

$\square$ Immediately

․ After internal communication with library staff

$\square \quad$ After message is approved by university

口 Once more information is gathered and a plan is in place

$\square$ When we start receiving questions from stakeholders/media

$\square \quad$ Other (please describe):

8D. If your library does not communicate staff reductions, why not? Check all that apply.

$\square \quad$ To minimize negative publicity

$\square \quad$ To minimize complaints

To buy time/hope to fix situation

$\square$ Following orders from library administration

$\square$ Following orders from university administration

$\square \quad$ I don't know why

$\square$ We did not feel it should be communicated

$\square$ Communication is the responsibility of a different campus unit

Other (please describe):

\section{Access Issues}

9. Does your library communicate access issues (such as database outage/updates or closed stacks/departments) to your campus stakeholders (faculty, students, and others)?

口 Yes

$\square$ No

I don't know 
$\square$ We have not had this event

\{If "I don't know" or "we have not had this event," skip to question 10.$\}$

\{If "no," skip to question 9D.\}

9A. Who communicates access issues to your campus stakeholders? Check all that apply.

$\square$ Library administration

$\square \quad$ Library communication/PR department

$\square$ University administration or communication department

$\square$ Collection development

$\square \quad$ Liaison librarians

$\square$ Access/public services

$\square \quad$ Other (please describe):

9B. How are access issues communicated to your stakeholders? Check all that apply.

$\square \quad$ Libraries website

$\square$ Campuswide email/newsletter from library

$\square$ Library social media

$\square \quad$ University website/email/social media

$\square \quad$ Email from liaison to academic units

$\square \quad$ Email from administration to academic units

$\square \quad$ Email from collection development/management to academic units

$\square \quad$ Face-to-face at faculty meeting

$\square \quad$ Other (please describe):

9C. When are access issues communicated to your stakeholders? Check all that apply.

$\square$ Immediately

$\square \quad$ After internal communication with library staff

$\square$ After message is approved by university

$\square$ Once more information is gathered and a plan is in place

$\square \quad$ When we start receiving questions from stakeholders/media

$\square \quad$ Other (please describe):

9D. If your library does not communicate access issues, why not? Check all that apply.

$\square \quad$ To minimize negative publicity

$\square \quad$ To minimize complaints

$\square$ To buy time/hope to fix situation

$\square$ Following orders from library administration

$\square \quad$ Following orders from university administration

$\square \quad$ I don't know why

$\square$ We did not feel it should be communicated

$\square$ Communication is the responsibility of a different campus unit

$\square \quad$ Other (please describe):

\section{Health and Safety Emergencies}

10. Does your library communicate health and safety emergencies (such as flooding, infestations, or criminal activity) to your campus stakeholders (faculty, students, and others)?
$\square$ Yes
$\square \quad$ No
I don't know 
We have not had this event

\{If "I don't know" or "we have not had this event," skip to question 11.\}

\{If "no," skip to question 10D.\}

10A. Who communicates health and safety emergencies to your campus stakeholders? Check all that apply.

$\square$ Library administration

$\square$ Library communication/PR department

$\square$ University administration or communication department

$\square$ Collection development

$\square \quad$ Liaison librarians

$\square$ Access/public services

$\square \quad$ Other (please describe):

10B. How are health and safety emergencies communicated to your stakeholders? Check all that apply.

$\square \quad$ Libraries website

Campuswide email/newsletter from library

$\square \quad$ Library social media

$\square \quad$ University website/email/social media

$\square \quad$ Email from liaison to academic units

$\square$ Email from administration to academic units

$\square$ Email from collection development/management to academic units

$\square \quad$ Face-to-face at faculty meeting

$\square \quad$ Other (please describe):

10C. When are health and safety emergencies communicated to your stakeholders? Check all that apply.

$\square \quad$ Immediately

$\square$ After internal communication with library staff

$\square \quad$ After message is approved by university

$\square$ Once more information is gathered and a plan is in place

$\square$ When we start receiving questions from stakeholders/media

$\square \quad$ Other (please describe):

10D. If your library does not communicate health and safety emergencies, why not?

$\square \quad$ To minimize negative publicity

$\square \quad$ To minimize complaints

$\square$ To buy time/hope to fix situation

$\square \quad$ Following orders from library administration

$\square \quad$ Following orders from university administration

$\square \quad$ I don't know why

$\square \quad$ We did not feel it should be communicated

$\square$ Communication is the responsibility of a different campus unit

$\square \quad$ Other (please describe):

\section{Other Information}

11. Are there any other negative events that required communication with your stakeholders and were not included in this survey? If so, please describe the event and how it was 


\title{
communicated.
}

12. What has been the response from your stakeholders based on your library's communication methods? Please list examples.

\author{
Thank you for completing this survey.
}

\section{Notes}

1. W. Timothy Coombs, Ongoing Crisis Communication: Planning, Managing, and Responding, 5th ed. (Los Angeles, CA: SAGE, 2019); Erika Hayes James and Lynn Perry Wooten, Leading under Pressure: From Surviving to Thriving before, during, and after a Crisis (New York, NY: Routledge, 2010); Michael L Kent, "What Is a Public Relations 'Crisis'? Refocusing Crisis Research," in The Handbook of Crisis Communication, eds. W. Timothy Coombs and Sherry J. Holladay (Hoboken, NJ: Blackwell, 2010), 705-12; Shearlean Duke and Lynne Masland, "Crisis Communication by the Book," Public Relations Quarterly 47, no. 3 (Fall 2002): 30.

2. Coombs, Ongoing Crisis Communication, 3-4; W. Timothy Coombs, "Crisis and Crisis Management," in Encyclopedia of Public Relations, ed. Robert L. Heath, vol. 1 (Thousand Oaks, CA: SAGE, 2005), 217.

3. Coombs, Ongoing Crisis Communication, 3-4.

4. Kent, "What Is a Public Relations 'Crisis'? Refocusing Crisis Research," 709.

5. James and Wooten, Leading under Pressure, 8.

6. W. Timothy Coombs, "Crisis Communication and Its Allied Fields," in The Handbook of Crisis Communication, eds. Sherry J. Holladay and W. Timothy Coombs (Oxford, UK: Wiley-Blackwell, 2010), 55, https://doi. org/10.1002/9781444314885.ch2.

7. E.W. Brody, Managing Communication Processes: From Planning to Crisis Response (New York, NY: Praeger, 1991), 175.

8. Robert J. Bies, "The Delivery of Bad News in Organizations: A Framework for Analysis," Journal of Management 39, no. 1 (January 2013): 137, https://doi.org/10.1177/0149206312461053.

9. Amanda B. Albert, “Communicating Library Value: The Missing Piece of the Assessment Puzzle," Journal of Academic Librarianship 40, no. 6 (November 2014): 634-37, https://doi.org/10.1016/j.acalib.2014.10.001; Amanda B. Albert, "Building Brand Love and Gaining the Advocacy You Crave by Communicating Your Library's Value," Journal of Library E Information Services in Distance Learning 11, no. 1/2 (January 2, 2017): 237-50, https://doi.org/1 0.1080/1533290X.2016.1193413; American Library Association (ALA), "Media Relations Handbook for Libraries" (November 27, 2012), available online at www.ala.org/advocacy/sites/ala.org.advocacy/files/content/ALA-MediaRelations-Handbook.pdf [accessed 12 March 2020]; Mark R. Gould, The Library PR Handbook (Chicago, IL: ALA Editions, 2009); Lauren Comito, Grassroots Library Advocacy, Special Reports (Chicago, IL: ALA Editions, 2012).

10. Jan Thenell, The Library's Crisis Communications Planner: A PR Guide for Handling Every Emergency (Chicago, IL: American Library Association, 2004).

11. Jodie L Borgerding, "It's Handled... Or Is It? The Status of Crisis Communication Planning in Academic Libraries," paper presented at Association of College and Research Libraries Conference, Portland, OR, March 25-28, 2015 (Chicago, IL: Association of College and Research Libraries, 2015), 358, available online at www.ala. org/acrl/sites/ala.org.acrl/files/content/conferences/confsandpreconfs/2015/Borgerding.pdf [accessed 12 March 2020].

12. Steven J. Bell, "Learning from Crucible Moments to Become Better Crisis Leaders: Tips for Leaders on Acquiring the Traits and Building the Skills Needed to Succeed in Crisis Leadership," AALL Spectrum (November/December 2018), 17, available online at https://www.aallnet.org/spectrum_issue/november-december-2018/ [accessed 12 March 2020].

13. Bell, "Learning from Crucible Moments to Become Better Crisis Leaders," 16.

14. Bibi M. Alajmi and Charlene L. Al-Qallaf, "Crisis-Management Content in LIS Curricula: Developing a Model for Future Improvement," Journal of Library Administration 58, no. 7 (October 3, 2018): 657-63, https://doi. org/10.1080/01930826.2018.1514838.

15. Ryan O. Weir, "Trimming the Library Materials Budget: Communication and Preparation as Key Elements," Serials Review 36, no. 3 (September 2010): 147-51, https://doi.org/10.1016/j.serrev.2010.06.003.

16. ALA, "Media Relations Handbook for Libraries."

17. Catherine Soehner, Ian Godfrey, and G. Scott Bigler, "Crisis Communication in Libraries: Opportunity for New Roles in Public Relations," Journal of Academic Librarianship 43, no. 3 (May 2017): 268-73, https://doi. org/10.1016/j.acalib.2017.03.003. 
18. Alexandria Chisholm and Brett Spencer, "The Displaced Librarian: Providing Research Services to Your Campus without a Library," College E Research Libraries News (2019).

19. Beatriz Betancourt Hardy, Martha C. Zimmerman, and Laura A. Hanscom, "Cutting without Cursing: A Successful Cancellation Project," The Serials Librarian 71, no. 2 (2016): 112-20, https://doi.org/10.1080/036152 6X.2016.1196635; Paul Metz, "Thirteen Steps to Avoiding Bad Luck in a Serials Cancellation Project," Journal of Academic Librarianship 18, no. 2 (1992): 76-82.

20. Alison Grant, "Benighted! How the University Library Survived the Auckland Power Crisis," Australian Academic E Research Libraries 31, no. 2 (January 2000): 61-68, https://doi.org/10.1080/00048623.2000.10755116.

21. Julia Zimmerman and Susannah C. Miller, "Shooting at Florida State University Libraries: The Act, Aftermath, and Response," Research Library Issues, no. 289 (July 2016): 5.

22. Robert E. Skinner, "'Nor Any Drop to Drink': New Orleans Libraries in the Aftermath of Hurricane Katrina," Public Library Quarterly 25, no. 3/4 (April 2006): 179-87, https://doi.org/10.1300/J118v25n03_15.

23. Wayne Jones, “Deciding Crises in Academic Libraries," MediaTropes 5, no. 2 (2016): 111.

24. Grant, "Benighted! How the University Library Survived the Auckland Power Crisis," 68; Thenell, The Library's Crisis Communications Planner, 4; David D. Perlmutter, "A Crash Course in Crisis Communication," Chronicle of Higher Education (February 9, 2018), available online at https://www.chronicle.com/article/A-CrashCourse-in-Crisis/242443 [accessed 12 March 2020].

25. Coombs, Ongoing Crisis Communication, 61-63; Steven J. Bell, “Learning from Crucible Moments: Lessons in Crisis Leadership," Library Leadership \& Management 33, no. 2 (2019): 5, https://doi.org/10.5860/1lm.v33i2.7327; M. Brooke Robertshaw, Michaela Willi Hooper, and Kerri Goergen-Doll, "Finding the Silver Lining... in the Serials Budget Crisis," Against the Grain (2017), 16; Ian I. Mitroff, Michael A. Diamond, and C. Murat Alpaslan, "How Prepared Are America's Colleges and Universities for Major Crises?" Change (January 2006), 64; Thenell, The Library's Crisis Communications Planner, 13.

26. Coombs, Ongoing Crisis Communication, 62; Mitroff, Diamond, and Alpaslan, "How Prepared Are America's Colleges and Universities for Major Crises?" 62; Perlmutter, "A Crash Course in Crisis Communication"; Thenell, The Library's Crisis Communications Planner, 26-33.

27. Coombs, Ongoing Crisis Communication, 62.

28. Mitroff, Diamond, and Alpaslan, "How Prepared Are America's Colleges and Universities for Major Crises?" 66.

29. Mitroff, Diamond, and Alpaslan, "How Prepared Are America's Colleges and Universities for Major Crises?" 65-66.

30. Borgerding, "It's Handled... Or Is It?" 363.

31. Borgerding, "It's Handled... Or Is It?" 365.

32. Borgerding, "It's Handled... Or Is It?" 365-66.

33. Jonathan Bernstein, "Making a Crisis Worse: The Eleven Biggest Mistakes in Crisis Communications," Journal of Promotion Management 12, no. 3/4 (2006): 40, https://doi.org/10.1300/J057v12n03_04; W. Timothy Coombs, "Parameters for Crisis Communication," in The Handbook of Crisis Communication, eds. W. Timothy Coombs and Sherry J. Holladay (Oxford, UK: Wiley-Blackwell, 2010), 27, https://doi.org/10.1002/9781444314885.ch1; Duke and Masland, "Crisis Communication by the Book," 31.

34. Coombs, "Crisis Communication and Its Allied Fields," 58.

35. Coombs, "Crisis Communication and Its Allied Fields," 58; Margaret Stewart and Maria Atilano, "Reputational Threats Online: Social Media as a Simultaneous Agent of Crisis and Tool for Response and Resolution in the Case Study of an American Academic Library," paper presented at International Crisis and Risk Communication Conference, Orlando, FL, May 12-14, 2018 (Orlando, FL: University of Central Florida, 2018), available online at https://digitalcommons.unf.edu/library_facpub/61 [accessed 12 March 2020]; Gregg Sapp and Peter G. Watson, "Librarian-Faculty Relations during a Period of Journals Cancellations," Journal of Academic Librarianship 15, no. 5 (November 1989): 287.

36. Robertshaw, Hooper, and Goergen-Doll, "Finding the Silver Lining... in the Serials Budget Crisis," 18; Chisholm and Spencer, "The Displaced Librarian," 94-95.

37. Thenell, The Library's Crisis Communications Planner, 15.

38. Coombs, Ongoing Crisis Communication, 76.

39. Paul Metz and Caryl Gray, "Public Relations and Library Weeding," Journal of Academic Librarianship 31, no. 3 (May 1, 2005): 275, https://doi.org/10.1016/j.acalib.2005.01.005; ALA, "Media Relations Handbook for Libraries," 34; Soehner, Godfrey, and Bigler, "Crisis Communication in Libraries," 272.

40. Bell, "Learning from Crucible Moments," 5.

41. Borgerding, "It's Handled... Or Is It?" 361-64.

42. Bell, "Learning from Crucible Moments," 5; Coombs, Ongoing Crisis Communication, 130; ALA, "Media 
Relations Handbook for Libraries," 34-35; Perlmutter, "A Crash Course in Crisis Communication."

43. Weir, "Trimming the Library Materials Budget," 150-51; Scott Baker and Morela Hernandez, "Communicating with Stakeholders When Bad News Is Uncertain," International Journal of Public Leadership 13, no. 2 (2017): 91-92, https://doi.org/10.1108/IJPL-11-2016-0051.

44. Baker and Hernandez, "Communicating with Stakeholders When Bad News Is Uncertain," 89.

45. Stewart and Atilano, "Reputational Threats Online," 25; Jia Wang and Holly M. Hutchins, "Crisis Management in Higher Education: What Have We Learned from Virginia Tech?" Advances in Developing Human Resources 12, no. 5 (October 2010): 561, https://doi.org/10.1177/1523422310394433; Perlmutter, "A Crash Course in Crisis Communication."

46. Baker and Hernandez, "Communicating with Stakeholders When Bad News Is Uncertain," 93.

47. Baker and Hernandez, "Communicating with Stakeholders When Bad News Is Uncertain," 92-94; Perlmutter, "A Crash Course in Crisis Communication."

48. Sapp and Watson, "Librarian-Faculty Relations during a Period of Journals Cancellations," 286-88; Robertshaw, Hooper, and Goergen-Doll, "Finding the Silver Lining... in the Serials Budget Crisis," 18; Metz, "Thirteen Steps to Avoiding Bad Luck in a Serials Cancellation Project," 80.

49. Coombs, "Crisis and Crisis Management," 222.

50. Coombs, Ongoing Crisis Communication, 140.

51. Thenell, The Library's Crisis Communications Planner, 22.

52. Garczynski, "Making the Cut," 25.

53. Metz and Gray, "Public Relations and Library Weeding," 274; Hardy, Zimmerman, and Hanscom, "Cutting without Cursing"; Stewart and Atilano, "Reputational Threats Online," 25.

54. Coombs, Ongoing Crisis Communication, 140.

55. Coombs, Ongoing Crisis Communication, 140.

56. Coombs, Ongoing Crisis Communication, 141.

57. Borgerding, "It's Handled... Or Is It?" 358.

58. Baker and Hernandez, "Communicating with Stakeholders When Bad News Is Uncertain," 91-92; Coombs, Ongoing Crisis Communication, 130; Bell, "Learning from Crucible Moments to Become Better Crisis Leaders," 18.

59. Coombs, "Crisis Communication and Its Allied Fields," 58; Baker and Hernandez, "Communicating with Stakeholders When Bad News Is Uncertain," 89; Bernstein, "Making a Crisis Worse," 40; Timothy, "Parameters for Crisis Communication," 27; Duke and Masland, "Crisis Communication by the Book," 30.

60. Bernstein, "Making a Crisis Worse," 40; Timothy, "Parameters for Crisis Communication," 27; Duke and Masland, "Crisis Communication by the Book," 31.

61. Borgerding, "It's Handled... Or Is It?" 361-64.

62. Borgerding, "It's Handled... Or Is It?" 361-64.

63. Coombs, Ongoing Crisis Communication, 76.

64. Garczynski, "Making the Cut," 16-27; Soehner, Godfrey, and Bigler, "Crisis Communication in Libraries," $268-73$.

65. Baker and Hernandez, "Communicating with Stakeholders When Bad News Is Uncertain," 91-94.

66. Borgerding, "It's Handled... Or Is It?" 358.

67. Coombs, Ongoing Crisis Communication, 140.

68. Garczynski, “Making the Cut,” 25; Thenell, The Library's Crisis Communications Planner, 22. 